Uncertainties in radon related to house specific factors and proximity to geological boundaries in England

\author{
NEZAHAT HUNTER ${ }^{a, 1}$, COLIN R MUIRHEAD $^{a}$, JON C H MILES $^{a}$ and J \\ DONALD APPLETON ${ }^{b}$ \\ ${ }^{a}$ Health Protection Agency, Radiation Protection Division, Chilton, Oxon. \\ OX11 0RQ UK \\ ${ }^{b}$ British Geological Survey (BGS), Keyworth, Nottingham NG12 5GG, UK
}

${ }^{1}$ Correspondence: Nezahat Hunter, HPA, Radiation Protection Division, Chilton, Oxon. OX11 ORQ UK. E-mail: Nezahat.Hunter@hpa.org.uk 


\title{
Uncertainties in radon related to house specific factors and proximity to geological boundaries in England
}

\author{
N Hunter, C R Muirhead, J C H Miles and J D Appleton
}

\begin{abstract}
Data collected as a part of a survey on radon concentrations from about 40,000 dwellings in England for six contrasting geological units were analysed to evaluate the impact of house specific factors (building characteristics and construction dates) and of proximity to geological boundaries. After adjusting for temperature and outdoor radon, each of geological unit, house type, double glazing and date of building were found to have a statistically significant influence on indoor radon concentrations and explained about $29 \%$ of the total variation between dwellings in logarithmically transformed radon values. In addition, there were statistically significant differences in radon concentrations according to proximity to geological boundaries categories for most of the geological units, but no consistent pattern could be detected.
\end{abstract}

\section{INTRODUCTION}

Exposure to radon in homes is the second leading cause of lung cancer in the UK after cigarette smoking and behaves like smoking in that the lung cancer risk increases with long term exposure (AGIR, 2009).

The main sources of radon in dwellings are soil and rocks. The rate of emission from these sources and hence the potential for concentration within houses varies considerably with location. Radon gas can enter a dwelling by the process of flow of air from the ground through cracks and other holes in the foundations. It is also known that variation in the weather and substructure type influence the amount of radon gas that enters a dwelling. Previous studies have shown that house-specific factors (e.g. house type, double glazing, floor type), structural alterations to the building (e.g. cavity wall insulation, blocking of a chimney and sealed floors), variation in the lifestyle of those living in the dwelling and rock type in the area of dwellings (geographical region) have notable effects on indoor radon levels (Hunter et al 2004; Gerken et al 2000; Gunby et al 1993). However, these studies included only a small proportion of houses in UK and did not examine geological boundaries.

We have performed analyses based on data for about 40,000 dwellings in order to evaluate the impact of house-specific factors for six contrasting geological units in UK and to assess differences in radon levels as a function of proximity to geological boundaries. This study formed an input to improvements in mapping methodology for England and Wales (Miles and Appleton 2005; Miles et al 2007). 


\section{HOUSE SPECIFIC FACTORS}

\section{Data}

The data were collected by the National Radiological Protection Board (now the Radiological Protection Division of the Health Protection Agency) throughout the UK as part of various surveys of exposure to radon in dwellings in UK (Miles \& Appleton 2005; Kendall et al 2005; Wrixon et al 1988). A total of 39,823 radon measurements were obtained in England. All measurements were carried out using alpha-etched track detectors that were exposed for three months in the main living area and in a sleeping area in the house. The mean radon concentration for each dwelling was calculated by taking a weighted average of the concentrations in the bedroom and living room, correcting for the temperature at the time of measurement (Miles 1998) and subtracting the mean outdoor radon concentrations of $4 \mathrm{~Bq} \mathrm{~m}^{-3}$ (Wrixon et al.1988). The geometric mean of the dataset was $61.7 \mathrm{~Bq} \mathrm{~m}^{-3}$ and the geometric standard deviation was 2.9. Figure 1 shows a histogram of the logarithms of the mean radon concentrations from all 39,823 dwellings in the dataset. These data are normally distributed (solid line).

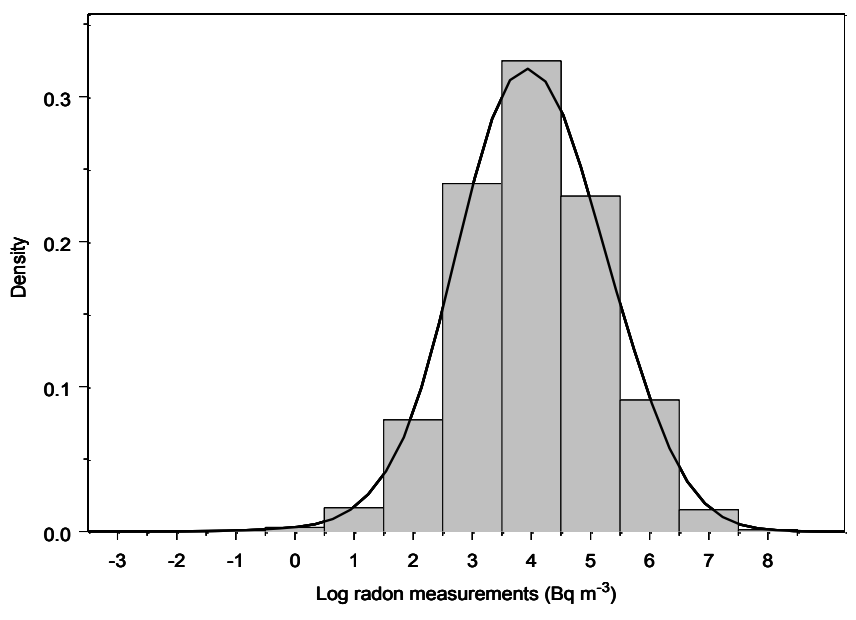

Figure 1: Histogram (with a normal distribution line) of logarithms of all radon concentrations, corrected for temperature and outdoor radon.

\section{Selection of covariates}

Various covariates were recorded, of which a subset most likely to affect radon concentrations was selected for this study. The variables chosen were: geological unit, house type, building year, living room and bedroom floor type, storey level for living room and bedroom, double-glazing, draught proofing and ownership. The covariates were categorised into the following groups:

- Geological units: NS-IRST (Jurassic Northampton Sand Formation; ironstone and sandstone), MCM-MDST (Carboniferous Pennine Middle Coal Measures Formation; mudstone), EXE-COSD (Permian Exeter Group; interbedded conglomerate and sandstone), CDF-DOLO (Permian Cadeby Formation; dolomite rock), CAIN-CCRG (Carboniferous to Permian Carnmenellis Intrusion; coarse grained granite) or BLL-LMST (Carboniferous Bee Low Limestone Formation);

- House Type: detached, semi-detached, mid-terraced, flat, other or unknown; 
- Double-glazing: none, all, partial or unknown;

- Building year: Pre 1900, 1900-1919, 1920-1944, 1945-1964, 1965-1976, 1977-92, post 1992 or unknown;

- Floor level (living area and bedroom): basement and ground floor, above the ground floor, bedroom above living room or unknown;

- Floor type (living area and bedroom): all solid, all suspended, mixed or unknown;

- Draught proofing: none, all, partial or unknown;

- Ownership: owner-occupier, rent from council, rent privately, other or unknown.

Table 1 shows summary statistics for temperature and outdoor radon corrected data from the whole dataset, for each of the geological units. Overall, the geometric mean and geometric standard deviation from 39,823 houses were $61.7 \mathrm{~Bq} \mathrm{~m}{ }^{-3}$ and 2.92 respectively. The lowest geometric mean was observed in MCM-MDST $\left(21 \mathrm{~Bq} \mathrm{~m}^{-3}\right)$ and the highest geometric means were found in CAIN-CCRG $\left(229.6 \mathrm{~Bq} \mathrm{~m}^{-3}\right)$ and BLL-LMST (129.3 $\mathrm{Bq} \mathrm{m}^{-3}$ ). As expected, these latter two geological units are also the units with the highest percentage of homes greater than the UK radon action level $\left(200 \mathrm{~Bq} \mathrm{~m}^{-3}\right)$.

\begin{tabular}{|c|c|c|c|c|c|c|c|}
\hline & \multicolumn{7}{|c|}{ Geological unit } \\
\hline & All & $\begin{array}{l}N S- \\
I R S T\end{array}$ & $\begin{array}{l}M C M- \\
M D S T\end{array}$ & $\begin{array}{l}E X E- \\
C O S D\end{array}$ & $\begin{array}{l}C D F- \\
D O L O\end{array}$ & $\begin{array}{l}C A I N- \\
C C R G\end{array}$ & $\begin{array}{l}B L L- \\
L M S T\end{array}$ \\
\hline Number of dwellings & 39,823 & 25,177 & 2,404 & 5,342 & 2,645 & 2,082 & 2,173 \\
\hline $\begin{array}{l}\text { Geometric Mean } \\
\left(\mathrm{Bq} \mathrm{m}^{-3}\right)\end{array}$ & 61.7 & 65.5 & 21.0 & 41.0 & 40.7 & 229.6 & 129.3 \\
\hline Geometric std. deviation & 2.92 & 2.77 & 2.14 & 2.13 & 2.47 & 2.45 & 2.78 \\
\hline$\%$ homes $>200 \mathrm{~Bq} \mathrm{~m}^{-3}$ & 14 & 14 & 0.2 & 2 & 4 & 56 & 33 \\
\hline
\end{tabular}

Table 1: Summary statistics for radon concentration data from 39, 823 houses

\section{Statistical Methods}

Factors affecting indoor radon concentrations were investigated using regression analysis. A multiplicative model was used to explain variations in indoor radon concentrations. The model takes the form:

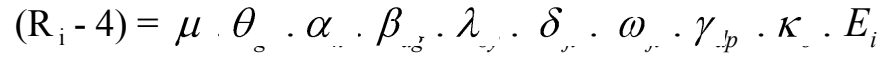

Here $R_{i}$ represents the average indoor radon concentration corrected for temperature of house $\mathrm{i}(\mathrm{i}=1, \ldots . ., 39,823)$ and $4 \mathrm{~Bq} \mathrm{~m}^{-3}$ is the mean outdoor radon concentration, $\mu$ represents the true average radon level for all dwellings in the study, $g$ represents the geological unit category $(g=1, \ldots, 6), h$ represents the house type category $(h=1, . ., 6), d g$ represents the double glazing category $(d g=1, . ., 4)$, by represents the building year category $(b y=1, \ldots, 8), f l$ represents the floor level of bedroom and living area category $(f l=1, . ., 4), o$ represents the ownership category $(o=1, . ., 5), d p$ represents draft proofing $(\mathrm{dp}=1, \ldots, 4), f t$ represents floor type of bedroom and living room 
$(f t=1, . ., 4)$ and $E_{i}$ represents random error in the measurement and is normally distributed with mean 0 and variance $\sigma$. The definitions of these categories are summarised in Table 3. The statistical model in Equation 1 was fitted to the logarithmically transformed data, using stepwise forward regression. The parameters $\mu, \theta_{0}, \alpha, \beta_{s}, \lambda, \delta, \omega_{,}, \gamma_{p}$ and $\kappa$ were defined in the model as fixed effects and were estimated from the logarithmic transformed data using the S-Plus statistical package.

\section{Results}

We studied a total of 39,823 dwellings and Table 2 shows the percentage of the variation in the logged radon data explained by each of the factors in the final model (Equation 1). The total percentage of variation explained by the factors in this model is $29 \%$. Geological units had a highly statistically significant influence and explained about $20 \%$ of the variation. House type, double-glazing, date of build, and the floor level of the living area and bedroom explained smaller percentages of the variation $(3.8 \%, 2.4 \%, 1.0$ and $1.0 \%$ respectively). The remaining three house specific factors (floor type, ownership and draught proofing) accounted for yet smaller percentages all together $(0.7 \%$ of the total variation). Further analyses were also performed for each geological unit to evaluate impact of house specific factors; as can be seen from Table 2 , house type, double glazing and date of building were the main contributors to the variation in logged radon concentrations for each of the geological units considered. The highest variation explained by these factors arose in CDF-DOLO (18.6\%) and the lowest variation was found in NS-IRST and BLL-LMST (both were 12\%).

\begin{tabular}{|c|c|c|c|c|c|c|c|c|}
\hline \multirow[b]{2}{*}{$\begin{array}{l}\text { Source of } \\
\text { Variation }\end{array}$} & \multirow[b]{2}{*}{$\begin{array}{r}\text { No. of data } \\
\text { categories }\end{array}$} & \multicolumn{7}{|c|}{$\%$ of variation explained } \\
\hline & & $\begin{array}{c}\text { All } \\
\text { geological } \\
\text { units }\end{array}$ & $\begin{array}{l}N S- \\
I R S T\end{array}$ & $\begin{array}{l}M C M- \\
M D S T\end{array}$ & $E X E-C O S D$ & $\begin{array}{l}C D F- \\
D O L O\end{array}$ & $\begin{array}{l}\text { CAIN- } \\
\text { CCRG }\end{array}$ & $B L L-L M S T$ \\
\hline No. of dwellings & & 39,823 & 25,177 & 2,404 & 5,342 & 2,645 & 2,082 & 2,173 \\
\hline Geological unit & 6 & 19.7 & - & - & - & - & - & - \\
\hline House type & 6 & 3.8 & 5.3 & 4.2 & 4.2 & 1.2 & 4.4 & 2.7 \\
\hline Double-glazing & 4 & 2.3 & 3.2 & 3.3 & 4.7 & 7.6 & 2.7 & 1.4 \\
\hline Date of building & 8 & 1.1 & 1.2 & 3.8 & 4.0 & 8.6 & 2.8 & 3.6 \\
\hline $\begin{array}{l}\text { Floor level of living } \\
\text { area and bedroom }\end{array}$ & 4 & 1.0 & 0.9 & - & 1.4 & - & - & 0.7 \\
\hline $\begin{array}{l}\text { Floor type of living } \\
\text { area and bedroom }\end{array}$ & 4 & 0.5 & 0.9 & 1.3 & 0.4 & 1.2 & 2.1 & 3.1 \\
\hline Ownership & 5 & 0.1 & 0.2 & 0.9 & - & - & 0.8 & 0.5 \\
\hline Draught proofing & 4 & 0.1 & 0.2 & 0.4 & - & - & - & - \\
\hline Total variation & & 28.6 & 11.9 & 13.9 & 14.7 & 18.6 & 12.8 & 12 \\
\hline $\begin{array}{l}\mu, \text { intercept } \\
\left(\mathrm{Bq} \mathrm{m}^{-3}\right)\end{array}$ & & 144 & 53 & 21 & 28 & 32 & 145 & 86 \\
\hline
\end{tabular}

Table 2: Percentage of total variation in logged radon concentrations explained by each of the factors selected for the final model. 
It is notable in Table 2 that the factors explaining the highest percentage of variation in the CDF-DOLO geological unit (ie. date of building and double glazing) explain a very low percentage of variation in the aggregated data. It is possible that this is due to the construction of housing estates with similar indoor radon levels. The houses on such estates will have the roughly same date of construction, whereas different estates built at different times may have different mean radon concentrations. The differences caused by this effect could well be important at a local level, but be averaged out when the whole data set is considered.

\begin{tabular}{|c|c|c|c|c|c|}
\hline Parameters & $\begin{array}{l}\text { Number of } \\
\text { dwellings }\end{array}$ & $\begin{array}{l}\text { Estimated } \\
\text { value }^{b}(\mathrm{SE})\end{array}$ & Parameters & $\begin{array}{l}\text { Number of } \\
\text { dwellings }\end{array}$ & $\begin{array}{l}\text { Estimated } \\
\text { value }^{b}(\mathrm{SE})\end{array}$ \\
\hline Geological unit & & & Date of building & & \\
\hline$\theta$, NS-IRST $^{a}$ & 25,177 & 1 & $\lambda$, pre $1900^{a}$ & 5,267 & 1 \\
\hline$\theta$, MCM-MDST & 2,404 & $0.24(0.02)$ & $\lambda, 1900-1919$ & 2,885 & $0.83(0.02)$ \\
\hline$\theta$, EXE-COSD & 5,342 & $0.55(0.02)$ & $\lambda, 1920-1944$ & 5,009 & $0.86(0.02)$ \\
\hline$\theta$, CDF-DOLO & 2,645 & $0.50(0.02)$ & $\lambda, 1945-1964$ & 6,147 & $0.77(0.02)$ \\
\hline$\theta$, CAIN-CCRG & 2,082 & $2.9(0.02)$ & $\lambda, 1965-1976$ & 5,940 & $0.74(0.02)$ \\
\hline$\theta_{-}$, BLL-LMST & 2,173 & $1.9(0.02)$ & $\lambda, 1977-1992$ & 7,675 & $0.72(0.02)$ \\
\hline House type & & & $\lambda$, post 1992 & 913 & $0.67(0.04)$ \\
\hline$\alpha$, detached ${ }^{a}$ & 12,198 & 1 & $\lambda$, unknown & 5,987 & $0.68(0.02)$ \\
\hline$\alpha$, semi-detached & 13,648 & $0.80(0.01)$ & $\begin{array}{l}\text { Floor type of living } \\
\text { area and bedroom }\end{array}$ & & \\
\hline$\alpha$, mid-terraced & 9,062 & $0.71(0.02)$ & $\omega$, all solid $^{a}$ & 4,796 & 1 \\
\hline$\alpha$, flats & 2,681 & $0.52(0.03)$ & $\omega$, all suspended & 15,159 & $0.72(0.02)$ \\
\hline$\alpha$, other & 579 & $0.86(0.04)$ & $\omega_{-}$, mixed & 14,346 & $0.72(0.02)$ \\
\hline$\alpha$, unknown & 1,655 & $0.83(0.05)$ & $\omega$, unknown & 5,522 & $0.79(0.02)$ \\
\hline Double glazing & & & Ownership & & \\
\hline$\beta$, none $^{a}$ & 13,349 & 1 & $\kappa$, owner $^{a}$ & 30,814 & 1 \\
\hline$\beta_{-}$, all & 5,939 & $1.66(0.02)$ & $\kappa$, rent from council & 5,652 & $0.86(0.01)$ \\
\hline$\beta$, partial & 17,657 & $1.27(0.01)$ & $\kappa$, rent privately & 1,532 & $0.92(0.03)$ \\
\hline$\beta$, unknown & 2,878 & $1.20(0.03)$ & $\kappa$, other & 344 & $0.95(0.06) *$ \\
\hline $\begin{array}{l}\text { Floor level of living area } \\
\text { and bedroom }\end{array}$ & & & $\kappa_{-}$, unknown & 1,481 & $0.90(0.05)^{*}$ \\
\hline$\delta$, ground $^{a}$ & 35,101 & 1 & Draught proofing & & \\
\hline$\delta_{-}$, above & 2,453 & $0.63(0.02)$ & $\gamma$, none $^{a}$ & 16,753 & 1 \\
\hline$\delta$, bedroom above liv. & 688 & $0.77(0.04)$ & $\gamma$, all & 1,668 & $1.15(0.03)$ \\
\hline \multirow[t]{2}{*}{$\delta$, unknown } & 1,581 & $0.86(0.05)$ & $\gamma$, partial & 12,209 & $1.10(0.01)$ \\
\hline & & & $\gamma$, unknown & 9,193 & $1.07(0.02)$ \\
\hline
\end{tabular}

${ }^{a}$ : Reference category; ${ }^{b}$ : Temperature and outdoor radon corrected; * Statistically not significant $(\mathrm{P}>0.05)$

Table 3: Estimated parameter effects for categories of each house specific factor, with standard errors (SE) in parentheses, based on the whole data set. 
The estimated model parameters, together with their standard errors (SE), are shown in exponent form in Table 3. These effects are described as multiplicative increases or decreases relative to the baseline category for each factor. Geological units were estimated to have the greatest statistically significant effect. The highest mean indoor radon levels were in CAIN-CCRG (Carnmenellis granite) and BLL-LMST (Bee Low Limestone Formation) type areas, and were higher by a factor of 2 and 3 times respectively than the levels in the NS-IRST (Northampton Sand Formation) type areas. The lowest radon levels arose in the MCM-MDST (Pennine Middle Coal Measures Formation) areas (see Table 3). The second most important factor in explaining variation in radon concentrations was the house type. Levels in semidetached houses were $20 \%$ lower on average than in detached houses; the corresponding reductions for mid-terraced houses and flats (relative to detached houses) were $29 \%$ and $48 \%$ respectively. Houses with all windows double glazed had $66 \%$ higher radon concentrations relative to houses with no double glazing; the corresponding increase for partially double glazed homes was $27 \%$.

The date of building was also found to have an effect on radon concentrations; the highest concentrations arose in houses built before 1900 and decreased with year of build (see Table 3). As was expected, houses with suspended wooden flooring had lower concentrations (by a factor of 0.72 ) relative to these with solid type flooring. Council houses had lower concentrations than owner occupied houses. The final factor found to be related to indoor radon concentrations was draught proofing; houses with full or some draught proofing had slightly higher $(15 \%$ and $10 \%$ respectively) concentrations than houses without draught proofing.

\section{POSITION OF GEOLOGICAL BOUNDARIES}

Geological boundaries on the BGS 1:50,000 scale DiGMapGB-50 digital geological maps have an average positional uncertainty of 50 metres. The uncertainty varies from place to place. For example, it may be particularly difficult for geologists to locate boundaries in areas where there are few exposures or topographic features and in areas that were built up when the geological survey was carried out (Miles \& Appleton 2005).

Consequently, misclassification may arise from allocation of indoor radon results to the incorrect geological unit, because the exact position of either the geological boundary or the house (or both) is uncertain. In other cases changes in the thickness, lithology, mineralogy and permeability of the underlying rocks, topographic slope, soil characteristics etc. may cause the radon potential near geological boundaries to be different from the radon potential in the centre of a mapped geological unit.

The dataset that was prepared to evaluate the impact of house specific factors was also used to analyse radon levels as a function of proximity to geological boundaries. As before, the radon measurements were corrected for temperature and outdoor radon. Precise information on the magnitude of uncertainty in individual geological boundaries is not available, but 50 metres is accepted by the British Geological Survey as an average uncertainty. This statistical evaluation sought to see whether there is evidence that measurements within either 50 metres or 100 metres of the mapped geological boundary are atypical of the geological unit as a whole. ArcMap/ArcView SHP files of 50 metre and 100 metre internally buffered geological 
polygons for a selected range of geological units were produced and indoor radon measurements with Ordnance Survey ADDRESS-POINT ${ }^{\circledR}$ co-ordinates were attributed according to the buffer zone in which they were located.

\section{Analyses of houses at 0-50 metres and at 50-100 metres from a geological boundary}

The radon levels were investigated in relation to the distance from the boundary of each of the six geological units considered earlier. For all of the units, statistically significant differences in radon levels were found between houses either 0-50 metres or 50-100 metres from the boundary, when compared with houses more than 100 metres from the boundary (Table 4). In particular, radon levels were lower in houses within 0-50 metres of the boundary for BLL-LMST, CDF-DOLO, EXE-COSD and NS-IRST, but were higher within 0-50 metres of the boundary for CAIN-CCRG. Furthermore, radon levels were statistically significantly lower in houses 50 to 100 metres of the boundary compared with those further away for BLL-LMST, EXECOSD, MCM-MDST and NS-IRST, but were statistically significantly higher for CAIN-CCRG and CDF-DOLO (see Table 4). No account was taken of the tectonic dip of the geological units. This may be a significant factor when the dip has a very low angle, for example with the NS-IRST.

\begin{tabular}{|c|c|c|c|c|c|c|}
\hline \multirow[b]{2}{*}{$\begin{array}{l}\text { Geological } \\
\text { unit }\end{array}$} & \multicolumn{6}{|c|}{$\begin{array}{l}\text { Estimated ratios of radon concentrations } \\
\qquad(95 \% \mathrm{CI})\end{array}$} \\
\hline & $N S-I R S T$ & $M C M-M D S T$ & $E X E_{-} C O S D$ & $C D F-D O L O$ & $C A I N-C C R G$ & $B L L-L M S T$ \\
\hline $\begin{array}{l}\text { Number } \\
\text { of records }\end{array}$ & 20,692 & 2,061 & 4,553 & 2,318 & 1,519 & 1,785 \\
\hline \multicolumn{7}{|c|}{ Distance to boundary (metres) } \\
\hline $0-50$ & $0.75(0.72,0.77)^{*}$ & $0.99(0.90,1.09)$ & $0.88(0.82,0.95)^{*}$ & $0.89(0.76,1.04)$ & $1.13(1.0,1.26)^{*}$ & $0.86(0.76,0.98)^{*}$ \\
\hline $50-100$ & $0.94(0.90,0.98)^{*}$ & $0.92(0.84,1.03)$ & $0.83(0.76,0.90)^{*}$ & $1.20(1.05,1.40)^{*}$ & $1.16(1.03,1.32)^{*}$ & $0.83(0.73,0.93)^{*}$ \\
\hline $100+^{a}$ & 1 & 1 & 1 & 1 & 1 & 1 \\
\hline $\begin{array}{l}\text { Radon level } \\
\left(\mathrm{Bq} \mathrm{m}^{-}\right)\end{array}$ & 67 & 15 & 39 & 33 & 192 & 132 \\
\hline
\end{tabular}

${ }^{a}$ : Reference category; *: Statistically significant at the $<5 \%$ level

Table 4: Summary results for regression analysis of radon data according to distance from the geological boundary for six geological units

\section{Analysis of data grouped by 100 metres intervals}

It is unclear whether the boundary effects described above might be due to inaccuracies in defining the boundary, or to physical processes that mean that radon availability near boundaries is different from that in the middle of a geological unit. It was decided, therefore, to extend the evaluation of variation with distance from a geological boundary by looking at findings over 100 metre intervals: namely $0-100 \mathrm{~m}$, 100-200 m, 200-300 m etc. Statistically significant differences in radon levels were found between boundaries categories for each of the six geological units studied, but no consistent pattern could be detected (not shown here). Where these differences 
extend hundreds of metres from the boundary, as in the case of EXE-COSD, it is clear that they could not be caused by uncertainties in the position of the boundary.

\section{DISCUSSION and CONCLUSIONS}

Multiple regression analysis has demonstrated that geology and house specific factors such as house type, double glazing, floor level of the bedroom/living area and date of building explain $29 \%$ of the total variation in logged radon levels in this dataset of around 40,000 dwellings. Geological unit alone explained about $20 \%$ of the variation, whereas house type, double glazing and other factors contributed smaller percentages. It would be possible to correct radon results for an individual dwelling for differences between that dwelling and a "standard" house. If a "standard" house were to be used in mapping, then these house-specific factors would significantly affect the variability in maps. However, Appleton and Miles (2009) have reported that the percentage of variation explained by geology is the same both with and without house standardised data. In the late 1990s, the UK Government Departments funding radon surveys requested that actual house data rather than "standardised" house data should be used for radon mapping.

This study also examined how much variation is explained by house specific factors in areas where geological units were mapped. The total radon variation explained by these house factors was highest in the Cadeby Formation (CDF-DOLO, 19\%) and lower in the Pennine Middle Coal Measures Formation (MCM-MDST, 14\%), Carnmenellis Intrusion (CAIN-CCRG, 13\%), Northampton Sand Formation (NSIRST, 12\%) and Bee Low Limestone Formation (BLL-MST, 12\%). Appleton \& Miles (2009) reported that grouping indoor radon data into $1 \mathrm{~km}$ grid squares explains $23 \%$ and $26 \%$ of intra-geological unit variation for NS-IRST and CAIN-CCRG respectively and $20 \%$ of the variation within CDF-DOLO. However, the study by Appleton \& Miles (2009) did not take account of house specific factors. Hence, it is difficult to deduce the relative contribution of house, geological, pedological and other factors to the overall variations within these geological units.

There were also statistically significant differences in radon levels between houses within 0 to 50 metres of a geological boundary compared to houses further than 100 metres from the boundary for four out of six geological units studied. The largest difference was a reduction of $25 \%$ for NS-IRST and an increase of $13 \%$ for CAINCCRG. For most of the geological units studied, radon concentrations were statistically significantly different between houses within 50-100 metres of the boundary and those further away. The largest differences ranged from an increase of $20 \%$ to a decrease of $17 \%$. Evaluation of measurement data grouped by 100 metre intervals away from a geological boundary indicated statistically significant differences in radon levels between some boundary categories for all six of the geological units studied, but no consistent pattern could be detected. It is concluded that the pattern of variation is so inconsistent between geological units and distances from boundaries that it is impractical to correct for uncertainty in the position of geological boundaries. 


\section{REFERENCES}

AGIR (Advisory Group on Ionising Radiation) 2009, Report of the independent advisory group on Radon in UK (in preparation)

Appleton J D and Miles J C H, 2009 A statistical evaluation of the geogenic controls on indoor radon concentrations and radon risk. J Env Radioactivity (submitted)

Gerken M, Kreienbrock L, Wellmann J, Kreuzer M, and Wichmann H E 2000 Models for retrospective quantification of indoor radon exposure in case-control studies. Health Phys. 78 268-278.

Gunby J A, Darby SC, Miles J C H, Green B M R and Cox D R 1993 Factors affecting indoor radon concentrations in the United Kingdom, Health Phys. 64 2-12.

Hunter N, Howarth C B, Miles J C H and Muirhead C R 2005 Year-to-year variations in radon levels in a sample of UK houses with the same occupants, pp: 438-447, NRE-VII : $7^{\text {th }}$ Int. Symp. on the Natural RadiationEnvironment (J P McLaughlin, S E Simoloulos and F Stainhäusler eds), Elsevier Ltd, Amsterdam.

Kendall G M, Green B M R, Miles J C H and Dixon D W 2005 The development of the UK radon programme. Journal of Radiological Protection 25: 475-492.

Miles JCH,1998 Mapping radon-prone areas by lognormal modelling of house radon data. Health Phys 74, 370-378.

Miles J C H, Appleton J D, Rees D M, Green B M R, Adlam K A M and Myers A H 2007 Indicative Atlas of radon in England and Wales. HPA-RPD-033, Chilton. www.hpa.org.uk

Miles J C H, Appleton J D 2005 Mapping variation in radon potential both between and within geological units J Radiol. Prot. 25 257-276.

Wrixon A D, Green B M R Lomas P R Miles J C H Cliff K D Francis E A Driscoll C M H James A C and O'Riordan M C 1988 Natural radiation exposure in UK dwellings, NRPB R190. London: HMSO. 